7th International Symposium on Superalloy 718 and Derivatives

Edited by: E.A. Ott, J.R. Groh, A. Banik, I. Dempster, T.P. Gabb, R. Helmink, X. Liu, A. Mitchell, G.P. Sjöberg, and A. Wusatowska-Sarnek

TMS (The Minerals, Metals \& Materials Society), 2010

\title{
EFFECT OF TEMPERATURE AND STRAIN DURING FORGING ON SUBSEQUENT DELTA PHASE PRECIPITATION DURING SOLUTION ANNEALING IN ATI 718PLUS ${ }^{\circledR}$ ALLOY
}

\author{
Erin McDevitt \\ ATI Allvac \\ 2020Ashcraft Ave., PO Box 5030 \\ Monroe, NC 28111-5030 \\ Keywords: ATI 718Plus, Delta Phase, Microstructure, Heat treatment \\ ( 718Plus is a registered trademark of ATI Properties, Inc.
}

\begin{abstract}
ATI 718 Plus ${ }^{\circledR}$ alloy relies upon grain boundary precipitation of the delta phase in order to achieve good resistance to notch failure. Delta phase precipitation can occur when forging at subsolvus temperatures or during solution annealing. Precipitation of delta phase during solution annealing can be affected by the interaction of forging temperature and strain during hot working whereby the combination of high forging temperature and low strain can result in unsatisfactory delta phase precipitation. Additionally, delta phase precipitation can be affected by exposure to supersolvus temperatures after forging is complete. This paper describes the effect of thermal mechanical processing history on delta phase precipitation in ATI 718Plus alloy and provides guidance on best practices to achieve optimum microstructure.
\end{abstract}

\section{Introduction}

ATI 718Plus alloy is a new, gamma-prime-strengthened, Ni-Fe base superalloy suitable for use up to at least $704^{\circ} \mathrm{C}\left(1300^{\circ} \mathrm{F}\right)$ [1]. The alloy has been characterized and evaluated by many OEM's, both independently and as part of a Metals Affordability Initiative funded project [2, 3, 4]. Alloy development at ATI Allvac is complete, and commercial application of the alloy began in earnest in 2010. Initial applications for the alloy include static parts such as turbine engine rings and cases. However, the temperature capability and manufacturability of ATI 718Plus alloy has also lead to the alloy being considered for disk applications.

The mechanical properties of ATI 718Plus alloy are strongly linked to microstructure. Grain boundary delta phase may be required to insure good notch ductility [5], and grain size and gamma-prime size affect strength, creep resistance, and creep crack growth rate [6]. Other authors [7] suggest that low angle grain boundaries provide resistance to cracking in notched stress rupture tests. Therefore, control of microstructure through thermal mechanical processing and heat treatment is important to manufacturers of parts such as engine disks and cases. This paper discusses how hot working and subsequent heat treatment impact the precipitation of delta phase in 718Plus alloy and provides some guidance for disk forgers and ring forgers to achieve a desirable microstructure.

Delta phase in ATI 718Plus alloy is thought to play a role similar to that in alloy 718, namely as a grain boundary precipitate phase that helps provide resistance to notch failure and high temperature embrittlement $[8,9]$. Delta phase in alloy 718 is also used during hot working to pin 
grain boundaries and produce a finer average grain size [10]. In ATI 718Plus alloy, the delta solvus temperature is about $999^{\circ} \mathrm{C}\left(1830^{\circ} \mathrm{F}\right)$ and the nose of the TTT curve for delta phase precipitation is about $927^{\circ} \mathrm{C}\left(1700^{\circ} \mathrm{F}\right)[11]$.

One of two general hot working and heat treatment routes are typically used in manufacturing ATI 718Plus alloy rings or closed die forgings: supersolvus forging ( $>$ delta solvus) or subsolvus (< delta solvus) forging followed by subsolvus solution annealing with the solution annealing temperature chosen to optimize the delta phase distribution in the microstructure [5]. When forging is conducted at a temperature greater than the delta phase solvus, solution annealing is performed at a generally lower temperature, e.g. $954^{\circ} \mathrm{C}\left(1750^{\circ} \mathrm{F}\right)$, in order to precipitate sufficient delta phase in the structure. When subsolvus forging is performed, the as-forged structure already contains delta phase, so a generally higher temperature solution anneal, e.g. $968^{\circ} \mathrm{C}-$ $982^{\circ} \mathrm{C}\left(1775^{\circ} \mathrm{F}-1800^{\circ} \mathrm{F}\right)$, is often performed to prevent excess precipitation of the delta phase.

However, often there are additional processing steps that are used in fabricating a finished part that may subject a forging to a different thermal history, such as brazing, welding, post weld heat treatment, hot sizing, etc. These processes can affect the microstructure of ATI 718Plus alloy, in particular, the delta phase. Andersson [12] reported that after heating as-hot-rolled ATI 718Plus alloy to $1040^{\circ} \mathrm{C}\left(1904^{\circ} \mathrm{F}\right)$ for 30 minutes, delta phase failed to precipitate during a subsequent standard solution annealing cycle. The author has also observed that delta phase precipitation can be significantly affected by the combination of hot working temperature and the amount of strain in the final reduction step prior to solution annealing and age hardening. Therefore, this investigation was executed to investigate the effects of hot working strain, hot working temperature, and post hot working thermal exposure on delta phase precipitation in ATI 718Plus alloy.

There have been several studies of delta phase precipitation in "strain-free" alloy 718 [13] and a generally accepted TTT diagram for precipitation in the alloy has been developed. However, little research discusses the effect of forging strain on delta phase precipitation in alloy 718 . Cold working alloy 718 leads to higher nucleation rates and lower activation energy for delta phase nucleation [14]. Direct comparison to ATI 718Plus alloy is difficult because some delta phase formation in alloy 718 occurs due to transformation of $\gamma^{\prime \prime}$ phase into the delta phase. In ATI 718Plus alloy, little $\gamma^{\prime \prime}$ phase exists in the microstructure [15] and it is unlikely that it plays an important role in delta phase precipitation.

\section{Experimental Procedure}

Commercially-produced, $229 \mathrm{~mm}$ (9 in.) diameter, ATI 718Plus alloy billet from triple-melt (VIM/ESR/VAR) heat X27F-3 (composition listed in Table I) served as the starting stock for the forging and heat treatment experiments. Blocks measuring $51 \mathrm{~mm} \times 51 \mathrm{~mm} \times 76 \mathrm{~mm}(2 \mathrm{in} . \times 2$ in. $\times 2$ in.) were cut from the midradius location in the billet. Similarly, plates measuring $51 \mathrm{~mm} \times$ $19 \mathrm{~mm} \times 102 \mathrm{~mm}(2$ in. $\times 0.75$ in. $\times 4$ in.) were also cut from the midradius location. In both cases, the long axis of the blocks and the plates was parallel to the longitudinal direction in the billet. The blocks were subsequently forged into pancakes and the plates were hot rolled.

Table I. Chemical Composition of ATI 718Plus ${ }^{\circledR}$ Alloy Used in the Present Investigation (wt.\%)

\begin{tabular}{|c|c|c|c|c|c|c|c|c|c|c|c|c|}
\hline Heat & Ni & Co & Cr & Fe & Ti & Al & Nb & Mo & W & C & P & B \\
\hline X27F-3 & Bal. & 9.0 & 17.8 & 9.5 & 0.75 & 1.53 & 5.5 & 2.7 & 1.0 & 0.023 & 0.008 & 0.004 \\
\hline
\end{tabular}


The blocks were upset forged into pancakes of $25 \%$ or $50 \%$ of their original height in one step. The plates were hot rolled for a total reduction of $11 \%$ and $17 \%$, respectively, in multiple rolling passes with reheats between rolling passes. The plates reduced a total of $11 \%$ had 4 rolling passes and an average final reduction pass of 5\%; the plates reduced a total of $17 \%$ had 5 rolling passes and an average final reduction pass of 5\%. Individual blocks and plates were hot worked at five temperatures: $954^{\circ} \mathrm{C}\left(1750^{\circ} \mathrm{C}\right), 1010^{\circ} \mathrm{C}\left(1850^{\circ} \mathrm{F}\right), 1038^{\circ} \mathrm{C}\left(1900^{\circ} \mathrm{F}\right), 1066^{\circ} \mathrm{C}\left(1950^{\circ} \mathrm{F}\right)$, and $1093^{\circ} \mathrm{C}\left(2000^{\circ} \mathrm{F}\right)$. Each block or plate was held in a furnace at the forging temperature for $1 \mathrm{~h}$ prior to hot working. Each forging was water quenched after hot working. The hot rolled samples are thought to have cooled substantially during rolling due to the large surface contact area with the tooling and those samples experienced little adiabatic heating due to the small reductions in each rolling pass.

From each pancake forging, several metallographic specimens were extracted from the midheight, midradius location in the pancake. From the hot rolled plates, metallographic specimens were extracted in the transverse direction at the quarter width position in the plate. Metallographic specimens measured $13 \mathrm{~mm} \times 13 \mathrm{~mm} \times 6 \mathrm{~mm}(0.5$ in. $\times 0.5$ in. $\times 0.25$ in. $)$.

Table II. Summary of Hot Working and Heat Treatment Procedures

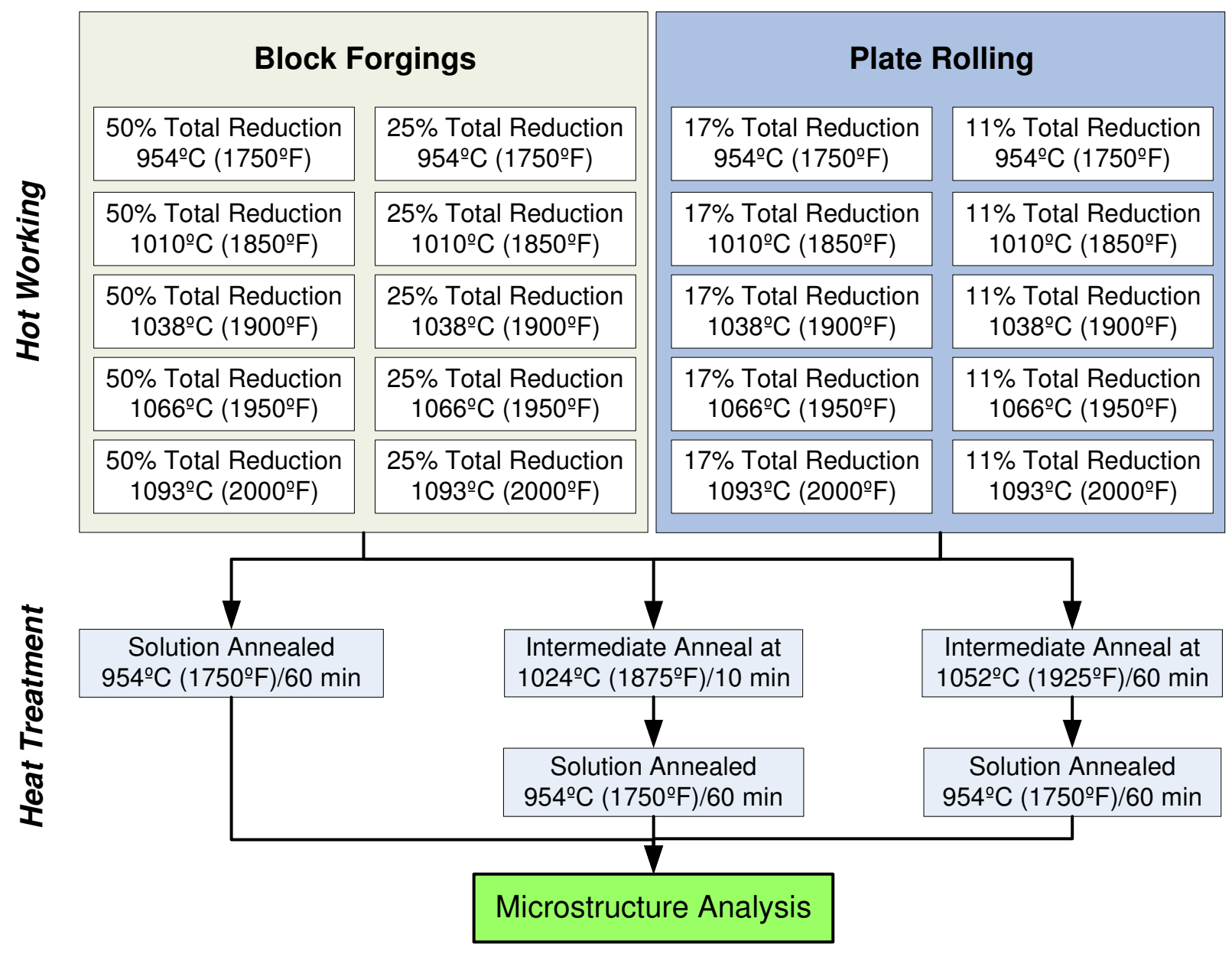


Individual metallographic samples from each forging were then heat treated using one of three heat treatment schedules: 1) Solution annealed at $954^{\circ} \mathrm{C}\left(1750^{\circ} \mathrm{F}\right)$ for 60 minutes, 2) Heated to $1024^{\circ} \mathrm{C}\left(1875^{\circ} \mathrm{F}\right)$ for 10 minutes - water quenched - solution annealed at $954^{\circ} \mathrm{C}\left(1750^{\circ} \mathrm{F}\right)$ for 60 minutes, 3) Heated to $1052^{\circ} \mathrm{C}\left(1925^{\circ} \mathrm{F}\right)$ for 1 hour - water quenched - solution annealed at $954^{\circ} \mathrm{C}$ $\left(1750^{\circ} \mathrm{F}\right)$ for 60 minutes. The as-forged condition was also examined. Optical and SEM microscopy samples were prepared using routine metallographic techniques and samples were etched using modified Kalling's reagent.

The amount of delta in each sample was measured using image analysis techniques and ImageJ software [16]. The grayscale optical micrographs were converted to binary images after manually adjusting the threshold. Then, when possible, grain boundaries were eliminated from the binary image to leave mostly delta phase. The volume percent delta phase reported corresponds to the area fraction of black pixels in the binary diagram. The fraction delta phase is generally overestimated because of the metallographic preparation method; however, the relative trends should provide information on how the amount of delta phase varies with processing.

\section{Results}

The as-forged grain size was consistent with the hot working temperature and strain. Grain size decreased with decreasing forging temperature and increasing strain (Figure 1). The as-hot rolled samples were unrecrystallized regardless of forging temperature. The $50 \%$ reduction pancake forgings and the $25 \%$ reduction pancake forgings were only partially recrystallized when forging was completed at $954^{\circ} \mathrm{C}\left(1750^{\circ} \mathrm{F}\right), 1010^{\circ} \mathrm{C}\left(1850^{\circ} \mathrm{F}\right)$, and $1066^{\circ} \mathrm{C}\left(1900^{\circ} \mathrm{F}\right)$.

Forgings made at $954^{\circ} \mathrm{C}\left(1750^{\circ} \mathrm{F}\right)$ contained some delta phase for all forging reductions (Figure 2 ). The amount of delta in the as-forged samples decreased with increasing forging reduction (Figure 3). At $1010^{\circ} \mathrm{C}\left(1850^{\circ} \mathrm{F}\right)$, only the hot rolled samples contained delta phase. At hot working temperatures greater than $1010^{\circ} \mathrm{C}\left(1850^{\circ} \mathrm{F}\right)$ no delta phase was observed in the asforged structures.

The $1 \mathrm{~h}$ solution anneal at $954^{\circ} \mathrm{C}\left(1750^{\circ} \mathrm{F}\right)$ was effective at precipitating the delta phase in all samples regardless of the amount of hot working strain or hot working temperature (Figure 4).

However, the amount of delta phase that precipitated and the distribution of delta phase were strongly influenced by hot working parameters. The amount of delta phase in the microstructure increased with increasing hot working strain and decreasing hot working temperature (Figure 5).

Delta phase precipitation during solution annealing occurred primarily on grain boundaries. Intragranular delta phase was observed in the hot rolled samples rolled at $954^{\circ} \mathrm{C}\left(1750^{\circ} \mathrm{F}\right)$, probably due to the lower hot working temperatures. On samples from forgings hot worked at a temperature that exceeded the delta phase solvus, grain boundary delta phase precipitation occurred only on a fraction of the grain boundaries in the microstructure (Figure 6).

Delta phase precipitation during solution annealing was strongly affected by a supersolvus heat treatment between hot working and solution annealing. Heating the samples to $1024^{\circ} \mathrm{C}\left(1875^{\circ} \mathrm{F}\right)$ for 10 minutes or to $1052^{\circ} \mathrm{C}\left(1925^{\circ} \mathrm{F}\right)$ for 1 hour prior to solution annealing prevented delta phase precipitation during the solution anneal cycle for all samples forged at a temperature of $1038^{\circ} \mathrm{C}$ 


\section{Hot-working Total Reduction}

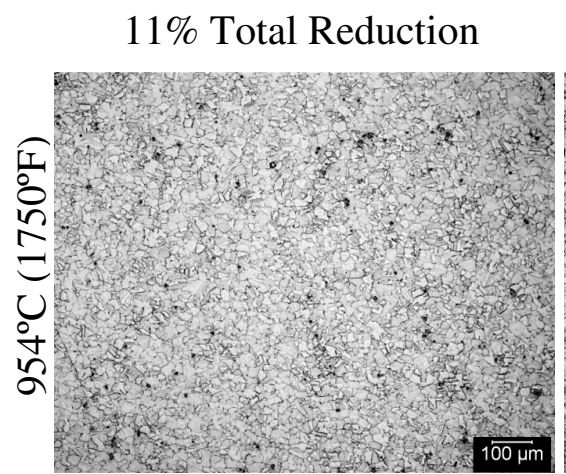

$25 \%$ Total Reduction
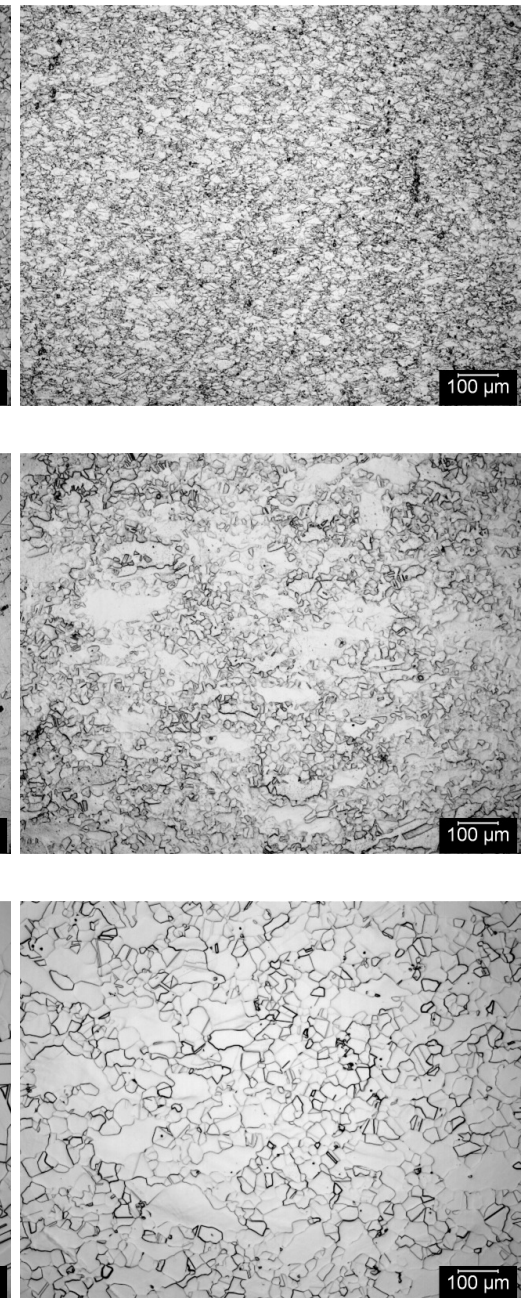

$50 \%$ Total Reduction
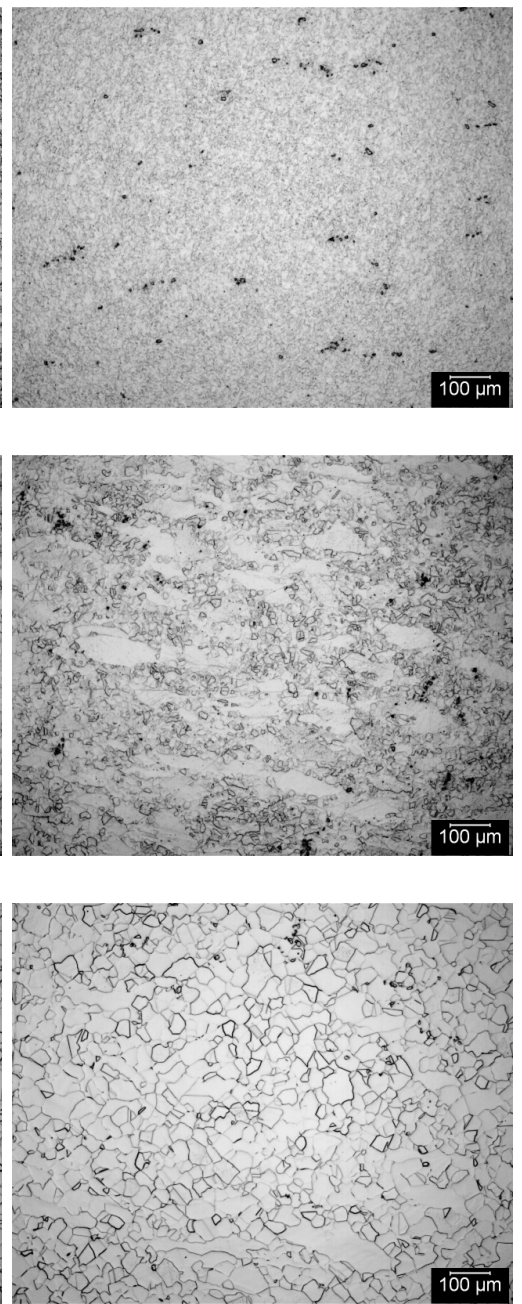

Figure 1. Representative optical micrographs from as-hot worked forgings as a function of forging temperature and hot working strain.

$\left(1900^{\circ} \mathrm{F}\right)$ and greater. A small amount of delta phase was present after solution annealing in hot rolled samples subjected to the $1024^{\circ} \mathrm{C}\left(1875^{\circ} \mathrm{F}\right)$ for 10 minutes intermediate anneal (Figure 7). The delta phase in those samples was primarily intragranular delta or delta phase that appeared to be associated with prior austenite grain boundaries rather than grain boundary delta.

\section{Discussion}

\section{As-Solution-Annealed Condition}

These results show that forging strain and forging temperature have an affect on delta phase precipitation during subsequent solution annealing. Lower forging temperature and higher strain promote delta phase precipitation during solution annealing. The forging strain effect is evident even with supersolvus forging temperatures where the as-forged microstructure contains little to no delta phase. 


\section{Hot-working Total Reduction}
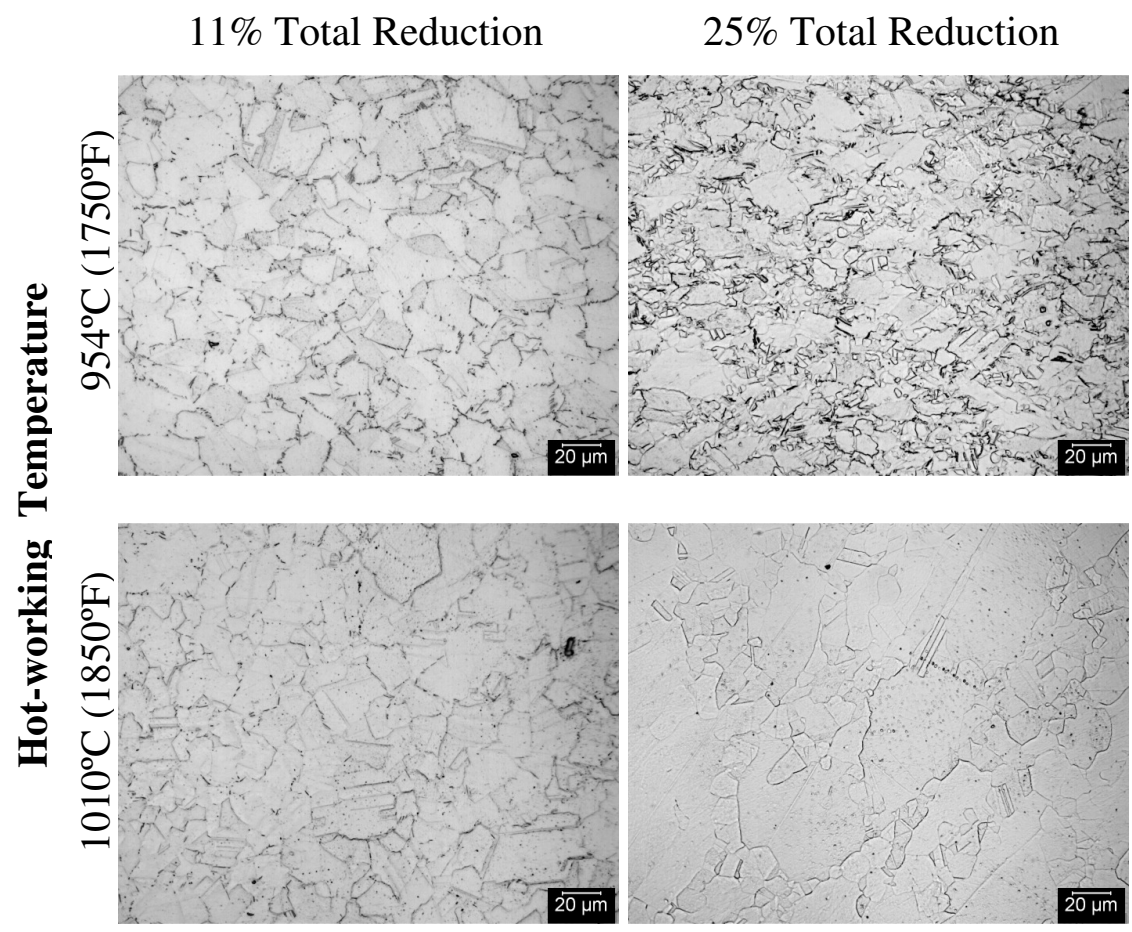

$50 \%$ Total Reduction
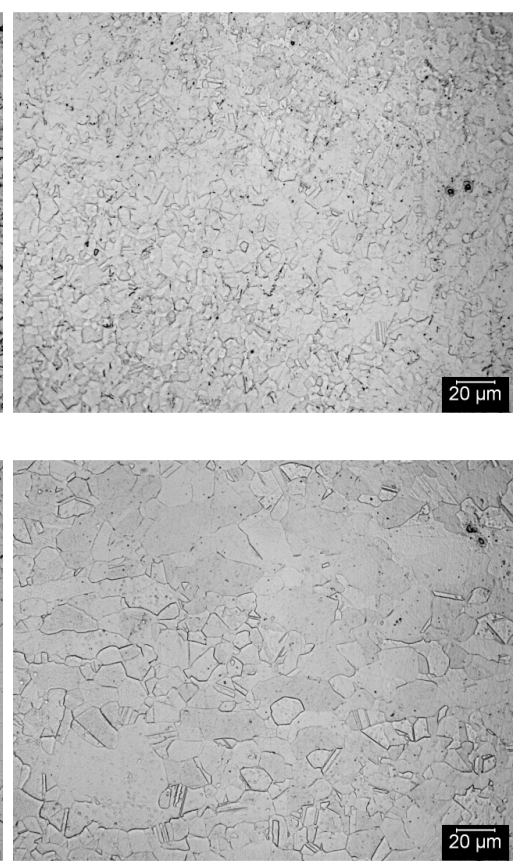

Figure 2. Representative optical micrographs from as-hot worked forgings as a function of forging temperature and hot working strain showing delta phase in the as-hot-worked microstructure.

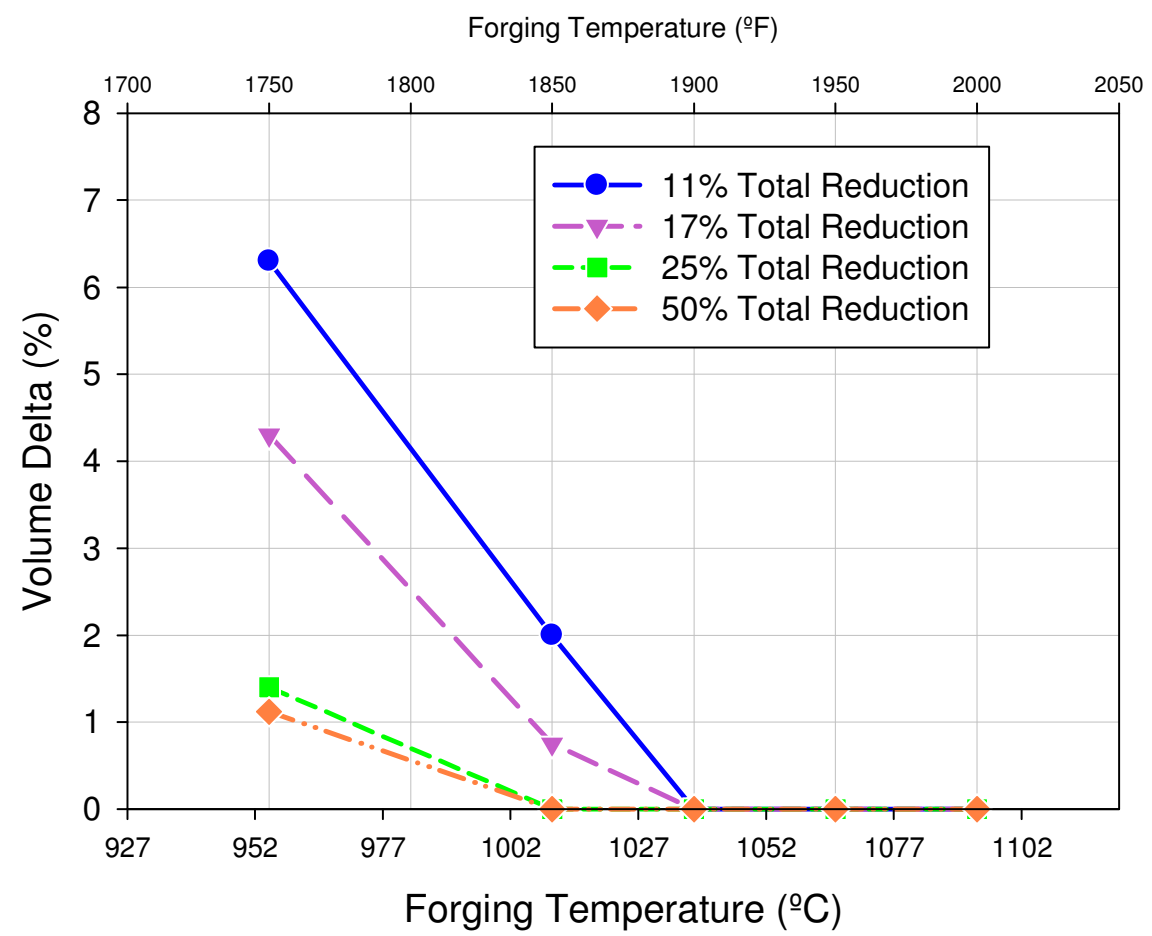

Figure 3. Volume percent of delta phase in as-forged material as a function of forging temperature and total hot working reduction. 


\section{Hot-working Reduction}
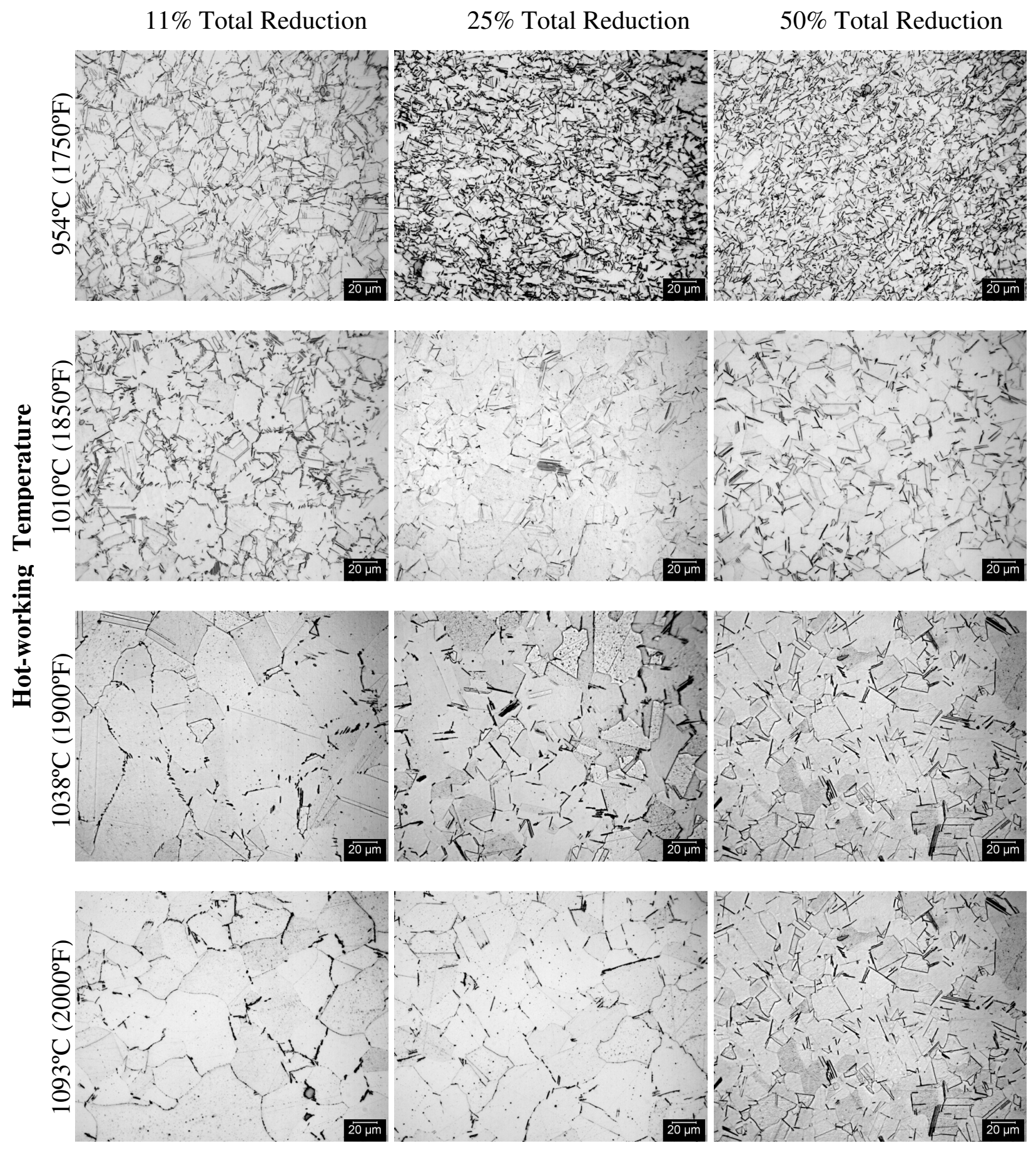

Figure 4. Representative optical micrographs from as-solution-annealed forgings $-954^{\circ} \mathrm{C} / 1 \mathrm{~h}$ $\left(1750^{\circ} \mathrm{F} / 1 \mathrm{~h}\right)-$ as a function of forging temperature and hot working strain showing delta phase in the microstructure. 


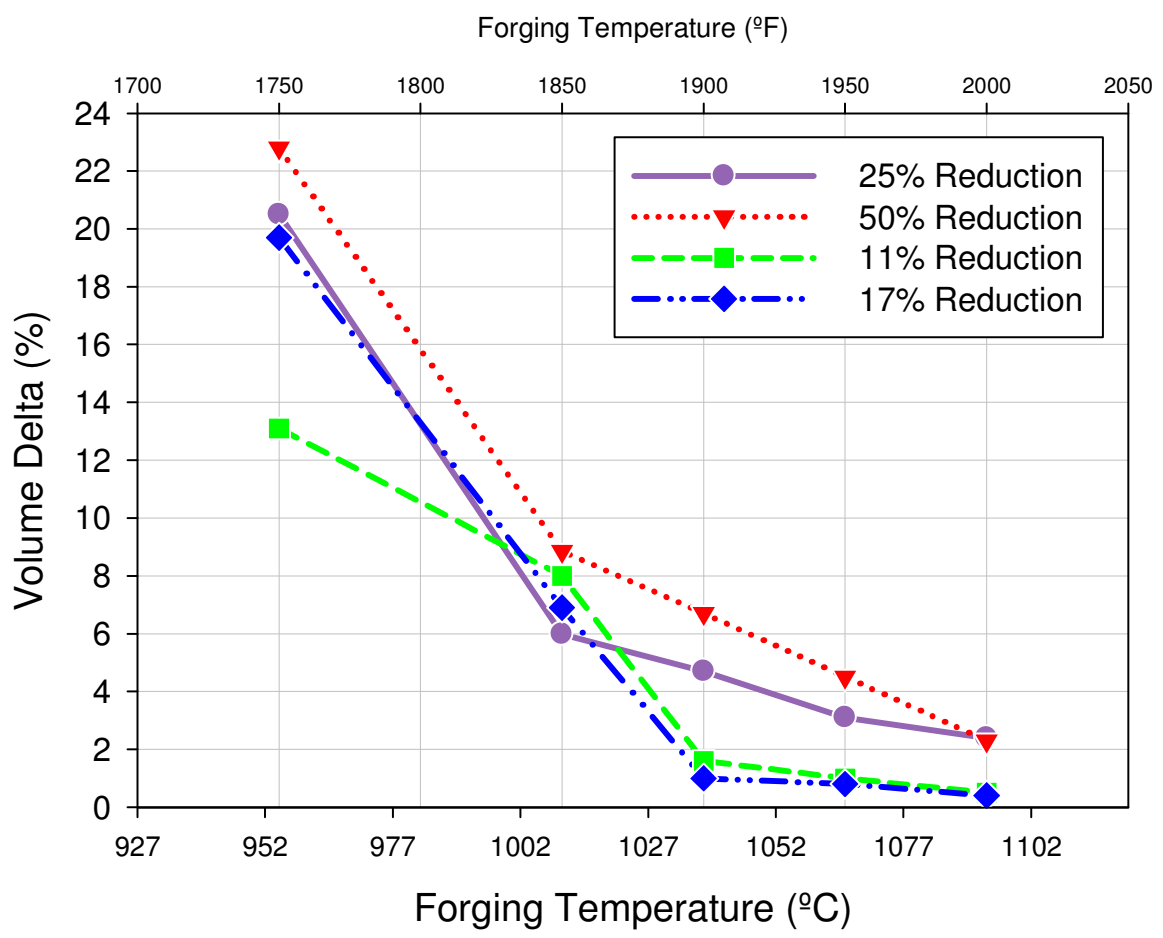

Figure 5. Volume percent of delta phase in as-forged material as a function of forging temperature and total hot working reduction.
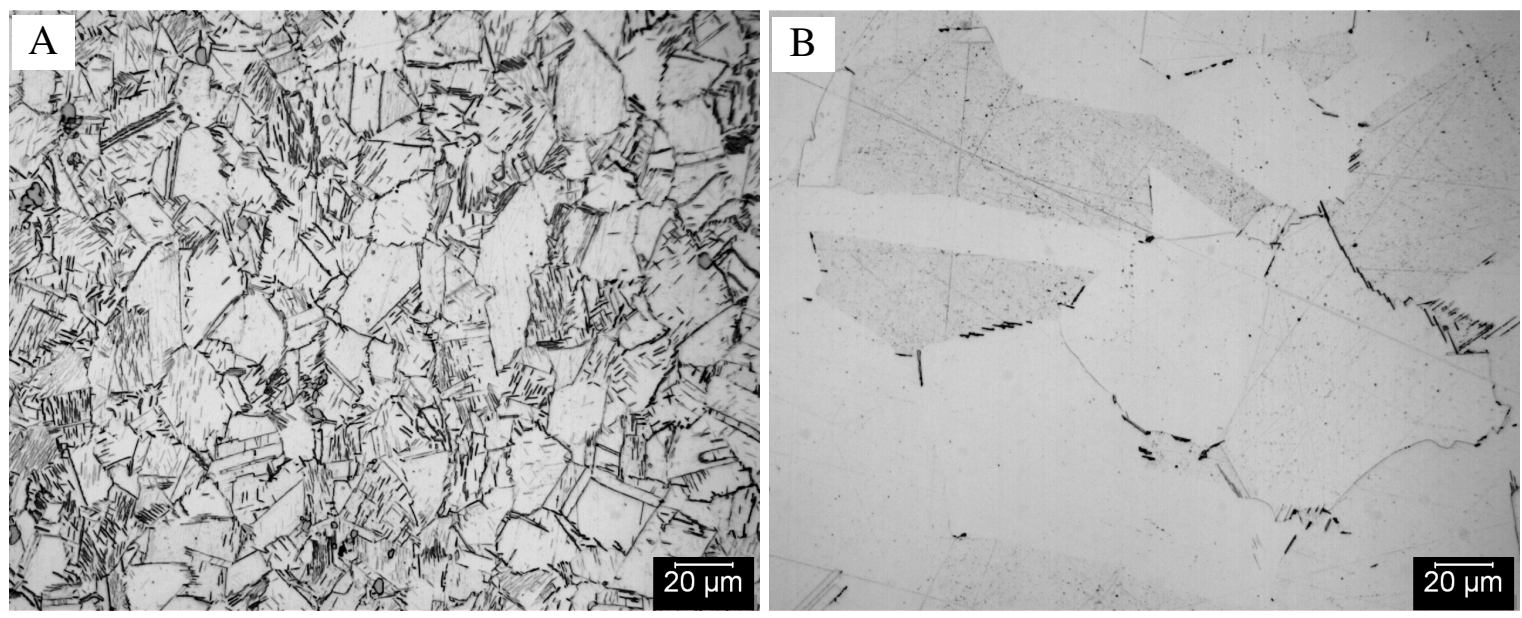

Figure 6. Delta phase precipitation in as-solution annealed microstructures. A) Intragranular delta phase precipitation in a sample hot rolled a total reduction of $17 \%$ at $954^{\circ} \mathrm{C}\left(1750^{\circ} \mathrm{F}\right)$. B) Selective grain boundary precipitation of delta phase in a sample hot worked $17 \%$ total reduction at $1066^{\circ} \mathrm{F}\left(1950^{\circ} \mathrm{F}\right)$. 


\section{Heat Treatment}

Intermediate annealed for 10 minutes at $1024^{\circ} \mathrm{C}\left(1875^{\circ} \mathrm{F}\right)$ then solution annealed $1 \mathrm{~h}$ at $954^{\circ} \mathrm{C}\left(1750^{\circ} \mathrm{F}\right)$

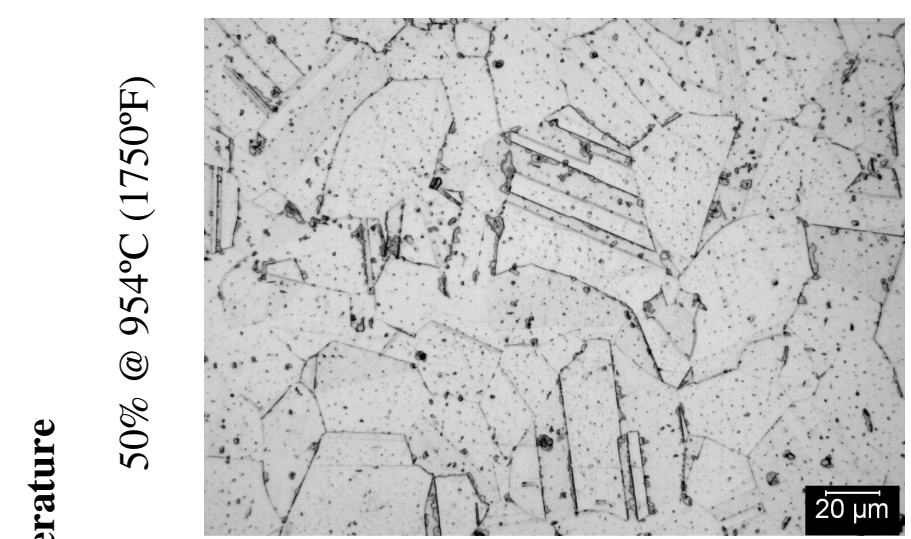

Intermediate annealed for $1 \mathrm{~h}$ at $1052^{\circ} \mathrm{C}\left(1925^{\circ} \mathrm{F}\right)$ then solution annealed $1 \mathrm{~h}$ at $954^{\circ} \mathrm{C}\left(1750^{\circ} \mathrm{F}\right)$
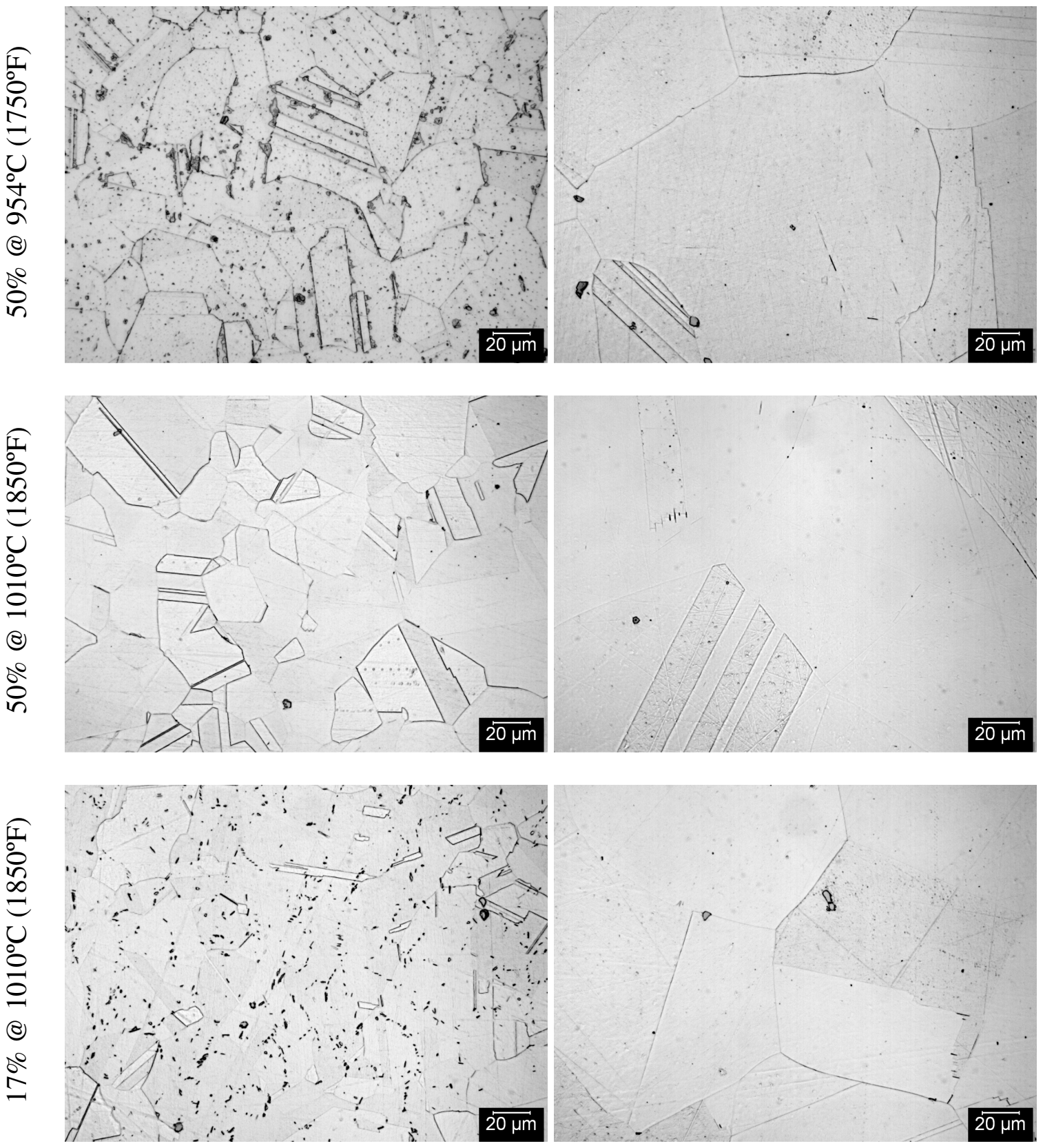

Figure 7. Representative optical micrographs showing the effect of an intermediate anneal on the microstructure of as-solution annealed samples as a function of hot working strain and temperature.

Another result is that the fraction of grain boundaries where delta phase nucleates increases as the forging strain increases at a given forging temperature. At small forging strains and higher forging temperatures, some grain boundaries exist where delta phase precipitation is more favorable, resulting in a non-uniform delta phase distribution. 
It is likely that austenite grain boundary defect structure is important in delta phase precipitation such that only the highest energy grain boundaries support nucleation of delta phase. Stotter et al [17] report similar observations of selective grain boundary precipitation of delta phase in supersolvus forged and solution annealed ATI 718Plus alloy. Those researchers report that the preferred grain boundaries are high angle grain boundaries; however, the grain boundary misorientation of the preferred nucleation sites was not reported.

Classical heterogeneous nucleation theory [18] describes the nucleation rate as being affected by the competition between the driving force for nucleation - the volumetric decrease in free energy associated with the formation of a volume of a second phase - and the retarding forces - the interfacial energy and the strain energy associated with the formation of the second phase. For grain boundary nucleation, the retarding force due to interfacial energy decreases as the energy of the parent phase grain boundary increases, provided that the nature of the parent phase grain boundary on the interfacial energy between new phase and the parent phase is negligible. In the case of 718Plus alloy, the formation of delta phase on high angle (high energy) grain boundaries is associated with a smaller barrier to nucleation and should result in a higher nucleation rate. Increasing grain boundary defect structure due to residual dislocations created during hot working would be expected to increase the interfacial energy of the austenite grain boundaries, even low angle grain boundaries, thus decreasing the barrier to nucleation. Therefore, with no change in driving force for nucleation, the nucleation rate for delta phase on all grain boundaries should increase as strain and grain boundary defect structure increases.

Desalos et al [19] observed a similar effect as that seen in ATI 718Plus alloy when studying the precipitation of ferrite from the parent austenite phase in low alloy steels. They report a significant increase in grain boundary nucleation rate with increasing hot working strain.

As forging temperature increases, one would expect a lower residual dislocation density associated with hot working and thus fewer defects associated with grain boundaries in the austenite. Fewer dislocations will reduce the energy of the grain boundaries and thus increase the barrier to delta phase nucleation. Hence, less delta phase is observed in as-solution annealed forgings hot worked at higher temperatures.

Unocic et al [7] report that grain boundary defect structure in addition to amount of delta phase impacts notch sensitivity in ATI 718Plus alloy and Dempster et al [20] reported a higher frequency of notch failures when forging at higher temperatures where fewer grain boundary defects would be expected.

\section{Intermediate-Annealed and Solution-Annealed Condition}

A short supersolvus heat treatment $\left(1024^{\circ} \mathrm{C}\left(1875^{\circ} \mathrm{F}\right)\right.$ for 10 minutes $)$ after hot working and prior to solution annealing prevented delta phase precipitation during a standard solution anneal cycle for most combinations of hot working temperature and reduction. Some small, nodular delta phase precipitates were observed in those samples hot worked at $954^{\circ} \mathrm{C}\left(1750^{\circ} \mathrm{F}\right)$. It is not clear if these delta phase particles precipitated during solution annealing or were present after forging at the subsolvus temperature and did not completely dissolve during the short intermediate anneal.

After a longer, higher temperature $\left(1052^{\circ} \mathrm{C}\left(1925^{\circ} \mathrm{F}\right)\right.$ for 1 hour) intermediate anneal and standard solution anneal, no delta phase was observed in the microstructure regardless of the 
starting condition, i.e. hot working temperature or reduction. The unrecrystallized forgings recystallized and grain growth occurred on all samples.

The absence of grain boundary delta phase after the combination of an intermediate anneal and solution anneal cycle further suggests that the grain boundary defect structure is of significant importance in delta phase precipitation in ATI 718Plus alloy. The intermediate anneal cycle temperatures were high enough for dislocation movement and annihilation at grain boundaries, thus resulting in lower energy grain boundaries.

The results which included an the intermediate anneal prior to solution annealing and those from a more conventional processing route without the intermediate anneal, indicate that there is not a strong driving force for delta phase nucleation at $954^{\circ} \mathrm{C}\left(1750^{\circ} \mathrm{F}\right)$ and that only with the presence of significant strain energy in the austenite, or defect structure in the austenite grain boundaries, can significant delta phase nucleation occur during a typical solution annealing time frame.

\section{Significance of Results}

These results can be important during closed die forging. In the case of supersolvus forging, areas in the part that see little deformation strain may be subject to insufficient delta phase nucleation during solution anneal treatment. Also, areas that experience significant adiabatic heating during forging may have a less than optimal delta phase structure in the final part.

In ring rolling, final sizing (small deformation after the part has been rolled to its final shape) should be performed below the delta phase solvus. Heating the ring above the solvus while only imparting small amounts of strain can lead to poor delta phase precipitation during solution annealing.

Heating for brazing (an intermediate heat treatment) may prevent delta phase precipitation during subsequent solution annealing. Similarly, the heat affected zone around a weld may be heated sufficiently such that delta phase precipitation is affected. Appropriate steps should be taken to insure proper microstructure after such processing.

\section{Future Work}

This investigation has shown that forging temperature and strain and material condition at the start of solution annealing heat treatment play an important role in delta phase precipitation in ATI 718Plus alloy. However, to date, the effects have been assessed only qualitatively. Future studies investigating which high angle grain boundaries support delta phase precipitation should be performed. The defect structure at grain boundaries as a function of forging parameters and heat treatment should be investigated using TEM. Better quantitative measurements of the amount of delta as a function of annealing time and temperature should be performed and the effective of strain on activation energy for nucleation should be determined.

\section{Conclusion}

Residual hot working strain and grain boundary defects play an important role in delta phase precipitation during solution annealing of ATI 718Plus alloy. Grain boundary delta phase precipitation is promoted by greater amounts of residual strain in the austenite. Higher forging reductions or forging at lower temperatures promote delta phase precipitation during solution annealing. 
Because grain boundary delta phase precipitation response can be poor when a forging is performed at a temperature well above the delta solvus, hot working metal temperatures for closed die forgings should not be in excess of about $1052^{\circ} \mathrm{C}\left(1925^{\circ} \mathrm{F}\right)$ in order to have good delta phase precipitation during solution annealing. Lower temperatures are required as forging strain decreases. In order for delta phase to precipitate easily, the final hot working step should be below the delta solvus temperature unless significant hot working strains are performed. Small strains, such as those associated with sizing of a rolled ring, may be insufficient to promote delta phase precipitation during solution annealing.

\section{References}

1. R.L. Kennedy, "Allvac ${ }^{\circledR} 718$ Plus ${ }^{\mathrm{TM}}$ Alloy, Superalloy for the Next Forty Years," Sixth International Special Emphasis Symposium on Superalloys 718, 625, 706 and Derivatives, Edited by E. A. Loria, TMS (The Minerals, Metals \& Materials Society), Pittsburgh, PA, (2005), $1-14$.

2. E. A. Ott, J. Groh, and H. Sizek, "Metals Affordability Initiative: Application of Allvac Alloy 718Plus ${ }^{\circledR}$ for Aircraft Engine Static Structural Components", Sixth International Special Emphasis Symposium on Superalloys 718, 625, 706 and Derivatives, Edited by E. A. Loria, TMS (The Minerals, Metals \& Materials Society), Pittsburgh, PA, (2005), 35-45.

3. R. Schafrik and R. Sprague; "Superalloy Technology-A Perspective on Critical Innovations for Turbine Engines”, Key Engineering Materials, 380 (2008), 113-134.

4. K. Schreiber, K. Loehnert, R. F. Singer, "Opportunities and Challenges for the New Nickel Base Alloy 718 Plus", Proceedings of Second Symposium on Recent Advantages of NbContaining Materials in Europe: Aerospace Applications - A Technical and Commercial Perspective, Essen, Germany (2006).

5. W. D. Cao and R.L. Kennedy, "Recommendations for Heat Treating Allvac 718Plus Alloy Parts," (Allvac Technical Report, February 24, 2006).

6. J. Tsang, R.M. Kearsey, P. Au, D. Seo, S. Oppenheimer, and W. Cao; "The Effect of Composition and Microstructure on the Fatigue and Creep-fatigue Behaviour of Allvac 718Plus Alloy"; Proceedings ECCC Creep Conference, Creep and Fracture in High Temperature Components: Design \& Life Assessment Issues, Zurich, Switzerland (2009) 1193-1204.

7. K. A. Unocic, R. W. Hayes, M. J. Mills and G. S. Daehn; "Microstructural Features Leading to Enhanced Resistance to Grain Boundary Creep Cracking in ALLVAC 718Plus", Metallurgical and Materials Transactions A, Published online November 17, 2009.

8. D.Cai, et al, "Dissolution kinetics of $\delta$ phase and its influence on the notch sensitivity of Inconel 718”, Materials Characterization, 58, 3, (2007), 220-225.

9. J. F. Muller and M. J. Donachie, "The effects of solution and intermediate heat treatments on the notch-rupture behavior of Inconel 718”, Metallurgical and Materials Transactions A , 6, 12 (1975), 2221-2227. 
10. C. Ruiz, A. Obabueki, and K. Gillespie, "Evaluation of the Microstructure and Mechanical Properties of Delta Processed Alloy 718” Superalloys 1992; (1992), 33-42.

11. X. Xie, C. Xu, G. Wang, J. Dong, W.Cao, R. Kennedy, “TTT Diagram of a Newly Developed Nickel-Base Superalloy- Allvac ${ }^{\circledR} 718$ Plus $^{\mathrm{TM}}$," Sixth International Special Emphasis Symposium on Superalloys 718, 625, 706 and Derivatives, Edited by E. A. Loria, TMS (The Minerals, Metals \& Materials Society), Pittsburgh, PA, October, 2005, pp. 193-202.

12. J. Andersson, G. Sjöberg, and S. Hatami, "Notch Sensitivity and Intergranular Crack Growth in Allvac 718Plus Superalloy", (Paper presented at ISABE-2007-1286, $18^{\text {th }}$ International Symposium on Air Breathing Engines, Beijing, China, September 2-7, 2007).

13. For example, V. Beaubois et al, "Short term precipitation kinetics of delta phase in strain free Inconel 718 alloy", Materials Science and Technology, 20, (2004) 1019-1026.

14. W.C. Liu, Z.L. Chen, and M. Yao, "Effect of Cold Rolling on the Precipitation Behavior of Delta Phase in INCONEL 718", Metallurgical and Materials Transactions A, 30A, (1999) 3140.

15. E.T. McDevitt and J. Bentley; "Microstructure and Mechanical Properties Of Direct Aged 718Plus Alloy"; Supplemental Proceedings: Volume 1: Fabrication, Materials, Processing and Properties; Materials for High Temperature Applications: Next Generation Superalloys and Beyond; TMS Annual Meeting, San Francisco, (2009).

16. ImageJ, v.1.42q, http://rsb.info.nih.gov/ij, W. Rasband, National Institute of Health, USA.

17. C. Stotter, C. Sommitsch, J. Wagner, H. Leitner, I. Letofsky-Papst, G. Zickler, W. Prantl, and M. Stockinger; "Characterization of $\delta$-phase in Superalloy 718Plus"; Int. J. Mat. Res.; 99 (2008) pp. $376-380$.

18. For example, D. A. Porter and K. E. Easterling, Phase Transformations in Metals and Alloys (London: Chapman \& Hall, 1992), 186 - 200.

19. Y. Desalos et al, Les Traitements Thermomechaniques (Comptes Rendus, $24^{\text {th }}$ Colloque de Metallurgie Saclay, France, 1981) 137.

20. I. Dempster, W.Cao, R. Kennedy, B. Bond, J. Aurrecoechea, "Structure and Property Comparison of Allvac ${ }^{\circledR} 718$ Plus ${ }^{\mathrm{TM}}$ Alloy and Waspaloy Forgings," Sixth International Special Emphasis Symposium on Superalloys 718, 625, 706 and Derivatives, Edited by E. A. Loria, TMS (The Minerals, Metals \& Materials Society), Pittsburgh, PA, October, 2005, pp. 155-164. 